\title{
AN ANALYSIS OF LANGUAGE CHOICE OF INTERETHNIC MARRIAGE DYAK-MADURESE COUPLES
}

\author{
Riski Amrina Sari \\ Sekolah Tinggi Bahasa Asing (STBA) Pontianak, Indonesia \\ riskiamrinasari@ymail.com
}

\begin{abstract}
This research explained the choice of language for Dyak-Madurese couples with interethnic marriage. In this research there are the aims of the research, this research aims to investigate the language choice used by interethnic marriage Dyak-Madurese families and to investigate the factors affecting language choice of interethnic marriage Dyak-Madurese couples. The method of this research was descriptive qualitative research. The researcher selected three families of Dyak-Madurese interethnic marriage as participants to achieve the aim of the research. The data were obtained by observing and interviewing. The results of this research have shown that interethnic marriage families Dyak-Madurese prefer the Indonesia language as their first language and are commonly used in everyday contact at the home domain. This research found that the children of the third family preferred a different language when interacting with their father, he preferred the Madura language, but he also uses the Indonesia language when communicating with his parents. The finding also showed that interethnic marriage Dyak-Madurese families use the Indonesia language in another domain such as neighborhood domain and with friends. The research also found that the children of the first and second families from interethnic marriage families were unable to speak the ethnic language, it has caused the younger children not to be taught the ethnic language. The children of the third family can speak Madura language because the father taught him the Madura language. In data there are three factors affecting language choice in interethnic marriage Dyak-Madurese couples, they are the participant, social context, the function of the language. Based on the research the interethnic marriage Dyak-Madurese families show a negative attitude toward their ethnic language, but the father of the third family has a positive attitude.
\end{abstract}

Keywords : langauge choice; interethnic marriage couple; heritage language; language attitude

\section{Introduction}

Language is one of the significant things for humans. People need a language when they communicate with others. By using language, people can fulfill their survival needs. Language makes it easier for people to share knowledge and communicate their thoughts or feelings. It means that language and culture can not be separated, because it plays a significant role in social interaction. Steele (1999) as cited in Kusuma (2014) said that language as vocabulary and rules for what a string of words might mean to a person. Furthermore, Sapir (1921) as cited in 
Rahmawati and Suharsono (2016) clearly stated that language is a purely human and noninstinctive method of communicating ideas, emotions, and desires using a system of voluntarily produced symbols such like auditory and they are produced by the so-called "organs of speech".

In Indonesia, there are many intermarriages couple. They choose spouses from different ethnicities. As Reed (2003) stated that Marriage is viewed differently by a couple of interracial marriages. This difference in marriage may reflect the linguistic choices of couples when they communicate with their spouses in the home domain, moreover with their children. This situation makes the challenges of choosing a language is always present because of their linguistic and cultural differences. Coulmas (2005) said that multilingual speakers cannot help but make choices for language is a social fact, culturally varied, group-specific, and governed by convention.

Madurese ethnic is the immigrant community in West Kalimantan. Madurese is in fifth grade after Dyak, Malay, Javanese, Chinese in West Kalimantan. This ethnic is spread in some areas in West Kalimantan, one of the areas is Anjungan. There are many Madurese ethnic in Anjungan. There are many Madurese who married with another ethnic such as Madurese-Dyak, Madurese-Javanese, and Mdurese-Malay.

Based on the reality in Luak village Anjungan found by the researcher, there are many interethnic marriage Dyak and Madurese couples. They did not use their heritage language when they communicate with their spouses and children. They used the Indonesia language when they communicate with each other moreover with their children. Based on the phenomena, the researcher conducted this research to analyze what language that they chose when they communicate with the family, the neighbor, and friends and how the attitude of interethnic marriage Dyak-Madurese couples toward their heritage language. The attitude from the language user can affect the maintenance of the heritage language.

Based on the explanation above, it needs to conduct another research about language choice toward interethnic marriage couples. As we know that in Indonesia there are many ethnicities and have different ethnic languages. There are many interethnic marriage couples in Indonesia too. It means that the existence of the heritage language is influenced by the attitude of the speaker toward their heritage language. If they choose their heritage language, and it means that language users have a positive attitude toward their heritage language.

\section{Language Choice}

Language choice is a big phenomenon in sociolinguistics, how the participants chose the appropriate language when they communicate in different domains. Language choice itself refers to how to select the language for different purposes for a different context. Fishman's (1976) language choice depends on the addressee, occasions, and topics. It means that different languages may apply in different domains. The language will be different when the speaker communicates for example wife to husband, to friends and students to a teacher. Context and place also can affect language choice.

Studying the language as a social and cultural phenomenon cannot be separated from the social context in which communication is happening. So, when the language users choose the varieties of language that switch with another code or language, it means that the social factors 
influence language choice. Actually, language choice is influenced by many factors, but one of the big influences is social factors because language is very related to the social context. It means that choosing the language, context, and situation of the language is very important. Actually, besides the parents, the language choice of the number of individuals outside the home can be influenced by the linguistics development of the children.

Holmes (2001) stated that some factors influence people to choose one language, they are the participant, social context, function, and topic of the discussion. These factors make the language users chose the appropriate language. The language used differently in different places. It means that social context affects the choices of the language. On another side based on Edwards (1997) as cited in Pebriyati and Setiawan (2014) in using the appropriate language divided into the domain, there are three important domains in people's life, they are home, schools, and workplace.

The language users chose the language differently based on the addressee. When speaking to the family such as parents, brother, sister, or friends children tend to use informal language to communicate, moreover use the mixing of the heritage language and national language. While in schools and the workplace, people usually use formal language.

Language choice one of the phenomena related to linguistic. Moreover, linguistics phenomena can create another phenomenon such as language shift and language death. The language will be shift and dead if there is the language users maintain and use the language. The language can be maintained by the language users if they keep the language by teaching, speaking and motivating the children / young generation to still use the heritage language, even though they come from interethnic marriage couples. Based on Garafanga (2010) one of the factors that can determine the language choice is language proficiency. The attitude towards a certain language is influenced by language proficiency.

\section{Language Attitude}

Holmes (1992) stated that a positive attitude towards language might support language maintenance in which the minority language is highly valued, while a negative attitude toward language can accelerate language shift, where an ethnic language is not highly valued. It means that the attitude from the language users determines the existence of the ethnic language. Language attitudes deal with the speakers' feelings towards language. Moreover, Crystal (1997) said that language attitudes are actually "the feelings people have about their language or the language of others."

Managan (2004) says that attitude is a person's readiness to react to a situation or event faced. This readiness can refer to mentality or a "behavior" attitude. Besides, Managan (2004) says that attitude is mental and neural readiness that is formed through experience that provides a dynamic direction or influence on a person's reaction to all objects or circumstances that concern that attitude.

According to Garafanga in Setiawan (2013) language proficiency is one of the factors which can determine the language choice. Language proficiency also influenced people's attitudes towards a particular language. 


\section{Previous Research}

The concept refers to language choice research which was done by some researchers. In the previous research about language choice by mixed marriage children by Dewi (2018) the title is "Language Choice Used by Mixed Marriage Children". In this research, the researcher used two children as the subject of the research. The result of the research, parents of the children succeed in applying their language to their children, so their children can speak two languages, Indonesia and English. So the children of this research are bilingual.

The other research about language choice used by Chinese family in Langsa. This research conducted by Yusmawati (2018). In this research, there were 15 families as the subject of the research. The data of this research from an interview conducted by the researcher. The result of this research the Chinese family chooses the Indonesia language as their language when they communicate.

The next research about language choice by Pebriyati and Setiawan (2014). This resaerch, there are two interethnic families, British-Indonesian couples as subject of this research. From the research the result showed that English was chosen by the families as their first language at home domain. The other result about factors influence the language choice they are participant, socil context and function. The last finding was most of the children of this family cannot speak ethnic language, so it will influence the maintenance of ethnic language.

From the previous research, Language Choice By Mixed Marriage Children (by Dewi), Language Choice Used By a Chinese Family in Langsa (by Yusmawati), Pebriyanti and Setiawan (2014) about Language Choice in
Interracial Marriage. The research will have a different result because the previous research and this research have different problems and subjects, moreover different languages. In this research different because this research focuses on language choice used by the interethnic marriage Dyak-Madurese couples in Anjungan, this research supported through interviews and observations, and conducted by applying descriptive qualitative methods. Moreover, this study is interesting because there is no previous study use Dyak-Madurese interethnic marriage as the subject, and how the children choose the language and factors affecting language choice. So, for the reason, the research about language choice of interethnic marriage DyakMadurese couples is needed to do. Moreover, this research has an advantage for the other researchers who want to research sociolinguistic.

\section{Research Method}

In conducting this study, the method used in this study descriptive qualitative research. Because this study is aimed to describe a certain phenomenon. In this study, the researcher observed the participant, from the daily activity and daily language that used when communicating to spouses, children moreover to the neighbor. After observing the researcher interviewing the participants. The researcher visits the houses and gives the question to get deep information about the language.

The subject of this study is the participant who gives the data or information related to the study. The participants in this study are five families. they are Dyak and Madurese couples who live in Anjongan District. The data were 
described descriptively based on the research problem, what language that they chose when they communicate in different domains and how the attitude of interethnic marriage DayakneseMaduranese couples toward their heritage language and how about the existence of their heritage language.

The technique of data collection was interview and observation techniques. The researcher conducted the interview and observation of the participant. The observation was used to find out the phenomena that occur in interethnic marriage couple. An interview to know more about the language attitude and language choice of the interethnic marriage couple. After interviewing the researcher transcript the interview as a result. The data were a transcript of the interview and the result of observation.

The data from the interview was analyzed through the following steps, transcribing the data, classifying the data, verifying the data, and concluding the language that chose/ used by the interethnic marriage couple moreover this research can conclude the attitude toward the heritage language.

\section{Results and Discussion}

The data of this research were taken form analyzing interview of the participant and from the observation.

\section{Language Choice of Interethnic Marriage families}

The first family, the mother usually use Indonesia langugage when communicating to her children and her husband. The father also use Indonesia language when communicating to his children and wife. They do not have attention to teach their children Dyak language or Madura language.

(1) "Saya selalu pakai bahasa Indonesia ketika berbicara dengan anak dan suami saya, tapi kalau dengan keluarga saya yang Dayak saya tetap pakai bahasa Dayak" (I ussually use Indonesia language when communicating to my children and my husband, but when communicating to my relatives who Dayaknese i use Dayak language.)

The second family as same as the first family, father and mother use Indonesia language to their children. They do not use Dayak language or Madura language to their children.

(2) "Kalau bicara ke anak dan suami saya pakai bahasa Indonesia begitu juga suami saya pakai bahasa Indonesia ke saya dan anak kami, jadi anak kami tidak ada yang pandai bahasa Dayak atau Madura" (I use Indonesia language when communicating to children and husband, and my my husband use Indonesia language to me and our children, so our children can not speak Dayak or Madura.)

The father of first and second families used Indonesia language when they communicate to the children and wife. because the mother of the first and the second families are Dyak, so the father of the first and second fmilies dicide to chose Indonesia language. They just use Madura language when they communicate with Madurese. 
(3) "Saya selalu pakai bahasa Indonesia kalau bicara ke istri dan anak saya, karena mereka sama sekali gak ngerti bahasa Madura, tapi kalau saya jumpa dengan keluarga dan teman yang Madura saya tetap pakai bahasa Madura." (i always use Indonesia language when communicating with my wife and children, because they don't understand Madura language, but if i meet my family and friend who Madurese i use Madura language).

The third family has different attitude in using language. Father of the third family ussually use Madura language to his children, and use Indonesia language to his wife. Mother of third family use Indonesia language when communicating to her children. The children can speak two languages, Indonesia language and Madura language (eventhough not fluent). When he communicate to his father he use the mixing of Madura language and Indonesia language. When communicating to his mother he use Indonesia language. When he talk to his friend who Madurese, he use the mixing of Madura and Indonesia language.

(4) "Kalau anak saya itu sama ayahnya pakai bahasa Madura dan sama temannya yang Madura pakai bahasa Indonesia yang kadangkadang dicampur dengan bahasa Madura dan kalau ngomong ke saya sehari-hari pakai bahasa Indonesia." ( he use Madura language if he speak to his father and to his friends who Madurese he use the mixing of Indonesia dan Madura language, and use
Indonesia language if he speak with me (mother)).

In the fourth family, the parents use Indonesia language when communicating with their children. They chose the Indonesia language because all the people around them use the Indonesia language when they communicate with each other.

(5) "kami orangtuanya pakai bahasa Indonesia aja kalau berbicara sama anak-anak kami, karena kalau pakai bahasa Madura atau Dayak mereka malah tidak mengerti, tambah lagi masyarakat sini dan tetangga sini kan orang melayu juga, jadi ya sudah terbiasa pakai bahasa Indonesia. Tapi kalau saya (ibu) saat berbicara sama keluarga saya yang Dayak ya tetap pakai bahasa Dayak, begitu juga dengan suami saya, tetap pakai bahasa Madura kalau berbicara dengan keluarganya yang Madura." (we as their parents use Indonesia language when communicating to our children, because if use Madura or Dyak language they do not understand, moreover all the people and neighbor are Malay people, so I feel comfort use Indonesia language).

(6) "saya juga kalau berbicara dengan anak dan istri saya, saya selalu pakai bahasa Indonesia, karena pernah saya coba pakai bahasa Madura, malah mereka tidak mengerti apa yang saya bilang. Jadi saya putuskan untuk memakai bahasa Indonesia. (I always use Indonesia language when communicating to my children and wife, $i$ have ever tried use Madura 
language, but they do not understand what $i$ said).

The fifth family, this family has different habit, father and mother of this family sometimes use their ethnic language when communicating to their children, but the children always use Indonesia language, they are not interest to study about ethnic language of their parents.

(7) "saya (ibu) terkadang pakai bahasa saya saat ngomong ke anak saya, tapi ya gitu lah anak saya tidak mengerti dan tidak mau mempelajarinya, kata mereka lebih suka pakai bahasa Indonesia, karena semua teman-teman pakai bahasa Indonesia. ( I (mother) sometimes use my ethnic language when communicating to my children, but they do not understand and they are not interest to study the ethnic language, they prefer choose Indonesia language, because all the friends use Indonesia language).

(8) "kalau saya ayahnya sering pakai bahasa saya, tapi ya sama tanggapan mereka tetap tidak tertarik untuk memakai bahasa saya dan ibunya. ( $i$ always use mau ethnic language, but still same their respon, they are not interest to study our ethnic language).

\section{Factors Affecting Language Choice}

Based on the theory of Holmes (2001) there are some factors affecting language choice of interethnic marriage couples Dyak-Madurese in Anjungan such as the participant, social context, function, and topic of the discussion.

In this research, the families choose a language based on the participant or addressee. Because the community is multilingual. The Father of the third family uses the Indonesia language when he communicates with his wife and uses Madura language sometimes mixing with Indonesia language when communicating with his children. In another case, the mothers of the first, second, and third families use Dyak language when communicating with their families who Dyak too, and use the Indonesia language when communicating with the husbands, children moreover to the neighbor.

On the other factor which affects language choice is social context, it means that when they communicate with others they choose the appropriate language 0\depending on the language that always uses in social. The father of the first, second, and third families use the Indonesia language in the workplace. The children use the Indonesia language at school. So it means that they choose the language based on the social context.

(9) "Saya (father) pakai bahasa Indonesia di tempat saya bekerja karena tempat saya kerja semuanya pakai bahasa Indonesia dan kebanyakan orang Melayu." ( $i$ always use Indonesia language in workplace, because all of them use Indonesia language and they are Malay).

(10) "Aku pakai bahasa Indonesia karena teman-teman semua pake bahasa Indonesia, Ibu guru juga pakai bahasa Indonesia". (I use Indonesia language because my friends use Indonesia language, the 
teacher use Indonesia language too). (Children from fist family)

(11) "Kamek pake bahasa Indonesia di disekolah, gak pande bahasa Madura dan Dayak." (i use Indonesia language at school, I cannot speak Madura and Dyak language). (children from the second family)

(12) "Aku pake bahasa Indonesia kalau disekolah, aku pande bahasa Madura tapi sedikit-sedikit karena ayah ngajarin bahasa Madura."(i use Indonesia language at school, I can speak Madura language but a little because of father taught me). (children from the third family)

The father of the third family teaches speak Madura language to his children because he realizes that the heritage language is important for them if they want to interact with the family and to the Madurese. So, it means that the function of language influence language choice.

(13) "Saya ngajarin bahasa Madura kepada anak saya agar dia bisa komunikasi dengan keluarga yang madura, dan kalau pulang kampung ke jawa jadi bisa mengerti kalau ada yang bahasa Madura." ( $i$ teach Madura language to my children, so he can speak Madura language, and if we come back to my hometown Java he can understand if there are speak Madura language).

\section{Language Choice of Interethnic Marriage families}

Based on the data, families from interethnic marriage couples choose the
Indonesia language as the first language to communicate in their family (at home domain). As the data (1, and 2 ) showed that the mother uses the Indonesia language when they communicate with her husband and children. Parents of the family did not use their ethnic language to their children when they communicate at home. The data (3) showed that the father of the families uses the Indonesia language when communicating with his wife and children. In data (4) the father of the third family has a positive attitude toward heritage language, so he taught Madura language to his children. So the children bilingual, based on the data, the children speak Indonesia language to the mother and use the mixing of Indonesia and Madura language to the father and friends who Madurese. So in the third family, the children include in bilingual. In data ( 5 and 6), the parents of this fourth family use the Indonesia language when communicating with their children. The data show that the parents have ever tried to use ethnic language, but the children are not interested. So the parents decide to choose the Indonesian language. In data (7 and 8) actually parents of this family have positive attitude toward their ethnic language, but when they try to use ethnic language, but there is no good respon from their children, so they decide to choose Indonesia language when communicating at home.

Children from interethnic marriage couples acquire languages from both their parents. Gupta (2010) stated that a child can acquire more than one language if adults around him/her frequently use more than one language. When parents of the interethnic married couples have a positive attitude in using their ethnic language, so their children can be multilingual speakers naturally. 


\section{Factors Affecting Language Choice}

On the other hand, there are some factors affecting language choice. Based on the data from three families, they choose the language to depend on the participant. They use ethnic language when communicating with the same ethnic such as family, friends. In data (5) the father of the families uses the Indonesia language in the workplace because the worker Malay and use Indonesia. In data $(6,7,8)$ the children said that at school they choose the Indonesia language because all the students and the teachers use the Indonesia language. it means that the data showed that language choice affected by social context. In the last data (9), the father said that he taught his children because of the function of the language if they communicate to family in Java.

Based on the data that the researcher gets from three families, they prefer to choose the Indonesia language when communicating. The parents of the families prefer to use the Indonesia language when communicating with each other, moreover to the children. And the only father of the third family that has a positive attitude toward ethnic language and taught Madura language to his children at home, so the children can speak Madura language even though just a little, and using Indonesia language when communicating to mother. Clyne (1991) said that a positive attitude is required in language maintenance. Introducing the ethnic language is one of a positive attitude.

\section{Conclusions}

This research focused on language choice in interethnic marriage couples who live in multilingual communities, they are Dyak-
Madurese couples. In multilingual communities, they have selected the language for communication. After analyzing the data of the research, interethnic marriage couples choose the Indonesia language as the first language in communicating. Indonesia's language is most frequently use by families. In the home domain, the families use the Indonesia language, even though the children of the third family can speak Madura language (only children of the third family), but the Indonesia language is the most frequently used when communicating at home. Even though parents of some of families ty to use their etchnic language, but the children can not understand about the ethnic language.

In choosing the language, three factors are affecting the choice of the language. Based on the data, DyakMadurese chooses the Indonesia language because of the participant/addressee, social context, and function of the language. Based on the data, the parents of this research have a negative attitude toward their ethnic language. The parents of these families did not introduce their ethnic language to their children. Only the father of the third family has a positive attitude toward the ethnic language, he speaks with his children use the Madura language, so the children bilingual.

By this research about language, the choice has been finished, the researcher expects that this research useful for the readers and make the readers understand about language choice and factors affecting language choice. And the researcher would like to give suggestions for the other researchers who interested in conducting relevant research especially for English department students and linguistic students to read this paper as additional information. Furthermore, the 
next researchers are suggested to use different data sources.

\section{References}

Coulmas, F. (2005). Sociolinguistics: The study of speakers' choice. Cambridge: Cambridge University Press.

Crystal, D. (1997). A dictionary of linguistics and phonetics. Oxford, UK: Blackwell.

Dewi, N., Dewi, S., \& Budiasa I.G. (2018). Language Choice Used by Mixed Marriage Children. Humanis, 22, 887-893. http:// doi. 10.24843/JH.2018.v22.i04.p08

Fishman, J. A. (1976). Bilingual education: an

$$
\begin{array}{lr}
\text { international } & \text { sociological } \\
\text { perspective. Rowley, } & \text { Mass.: } \\
\text { Newbury House. } &
\end{array}
$$

Gafaranga, Joseph. (2010). Medium request:

Talking language shift into being. Languae in Society 39 (2): 241-270.

Gupta, A. F. (2010). Bilingual and Multilingual Children: Another Perspective. Retrieved from Ask A Linguist FAQ website: http://linguistlist.org/askling/biling2.html.

Holmes, J. (2001). An Introduction to Sociolinguistics. United Kingdom: Longman.

Holmes, J. (1992). Learning about language:
An Introduction to

Sociolinguistic.london:Longman

Kusuma, B.H. (2014). ) Language Choice in Multilingual Society. A Sociolinguistic Study of Tanjung Luar Community. The University of Mataram.

Managan, K. (2004). Diglossia Reconsidered:

Language Choice and CodeSwitching in Guadeloupean Voluntary Organizations. Paper presented at Texas linguistic forum. Research Gate: Retrieved https://www.researchgate.net/pu blication/278785088 LANGUAGE CHOICE AND LANGUAGE ATTITU DES IN A MULTILINGUAL ARAB CANADIAN COMMUNITY QUEBEC - CANADA A

SOCIOLINGUISTIC_STUDY on 22 September 2018.

Pebriyati, N., \& Setiawan, S. (2014). Language Choice in Interracial Marriage Families: BritishIndonesian Couples. Litera Kultura, 2(1).

Rahmawati, N., \& Suharsono. (2016). The Language Choice of Foreign Students In Learning Bahasa Indonesia At Unesa.

Reed, J.M. (2003). How unmarried couples with children think about marriage. Paper presented at the annual meeting of the American Sociological Association, Atlanta Hilton Hotel, Atlanta, GA Online. Retrieved May 26, 2009 from http://www.allacademic.com/met a/p107471 index.html. 
Setiawan, S. (2013). Children's Language in a

Bilingual Community in East Java. Germany: Scholars' Press.
Yusmawati. Lestari, C., \& Hidayah, N. (2018).

Language Choice Used by Chinese Family in Langsa. Language Literacy, 2(2), 2580-8672. $\quad$ http://doi: 10.30743/II.v2i2.682. 